\title{
Legal and environmental factors hindering the development of scientific and technical cooperation in SCO countries
}

\author{
E. S. Anichkin*1 ${ }^{1}$ A. A. Vasilyev ${ }^{1}$, E. A. Kulikov ${ }^{1}$, A. Yu. Rezinkin ${ }^{2}$, A. A. Serebryakov ${ }^{1}$ \\ ${ }^{1}$ Altai State University, Barnaul, Russian Federation \\ ${ }^{2}$ Altai State Medical University, Barnaul, Russian Federation \\ *Corresponding author E-mail: rrd231@rambler.ru
}

Received: 08.09.2020. Accepted: 22.10.2020

\begin{abstract}
The present work is devoted to the analysis of problems in development of international scientific and technical cooperation between the Shanghai Cooperation Organization member-states. Among the main factors that determine the development of scientific and technological sphere, the most important are legal factors, the detailed analysis of which is presented for each member state of Shanghai Cooperation Organization. The study of legal factors hindering the development of scientific and technological cooperation is based on the peculiarities of national legal regulation of scientific and innovation activity and the shortcomings of international agreements within the SCO. The authors identify both internal and external legal factors that influence the development of international scientific and technological collaboration. The authors consider the state of legal regulation of national science and technology policy and the legal status of organizations involved in the development of science as internal legal factors. External legal factors include the existence of bilateral treaties between the countries of the Shanghai Cooperation Organization regulating scientific and technological cooperation, as well as the content of multilateral treaties on scientific and technological cooperation between all member states of the Shanghai Cooperation Organization. Based on the results of the study, the authors conclude that it is necessary to harmonize the national legislation of the Shanghai Cooperation Organization countries on the issues of legal regulation of scientific and technological cooperation, as well as to consolidate at the international level the legal mechanisms for implementation of certain aspects of cooperation in the scientific and technological fields.
\end{abstract}

Keywords: International cooperation; Environmental; Shanghai Cooperation Organization; Science; Innovation activity; Ecological, scientific and technical cooperation

\section{Introduction}

The development of international scientific and technological cooperation is conditioned by the growing costs of research and development, the complexity and multidisciplinary of scientific research, and the orientation towards solving problems related to the "big challenges of our time". Despite the strengthening of political, economic and cultural ties between the member states of the Shanghai Cooperation Organization (hereinafter - SCO), it should be noted that the development of long-term and effective scientific collaboration between them leaves much to be desired.

Among various factors that affect the development of international scientific and technological cooperation, legal factors play a special role. Unfortunately, these factors, as a rule, are not considered independent (Kandakova et al., 2016. However, in our view, the successful implementation of state science and technology policy at the international level requires detailed legal regulation. In this regard, special attention should be paid to assessing the state of national and international legal regulation of scientific and technological cooperation, i.e. legal factors.

A stable system of legal regulation of various spheres of public life is the key to successful functioning of the state. A well-developed legal framework for the regulation of various relations in science and technology and innovation contributes to making the country a reliable partner for the regional international community. At the same time, the legal framework alone is not sufficient for an effective policy on cooperation in science and technology. No matter how well defined the legal framework is, the lack of will to implement it and the lack of financial support will ruin any good initiative.

It seems that legal factors that directly affect the effectiveness of scientific and technical cooperation should include the state of legal regulation of national scientific and technical policy, the legal status of organizations tasked with the development of science, as well as the legal consolidation of intentions to develop scientific and technical cooperation through international agreements. The first two factors are internal, but they create important legal prerequisites for regulating scientific and S\&T cooperation at the international level.

A detailed analysis of the above legal factors in relation to the SCO member-states will make it possible to identify the "bottlenecks" that hinder the construction of a large-scale and sustainable system of scientific and technological cooperation within this international organization.

\section{Materials and Methods}

Issues of international scientific and technical cooperation are quite widely covered in the literature. As a rule, these studies consider the state of interstate cooperation in the field of science and technology between developed and developing countries, including some SCO countries. Thus, some studies are devoted to the analysis of scientific cooperation between the European Union and Russia (Haegeman et al., 2020) and between the European Union and China (Kwok et al., 2019). Other studies compare data 
for several developed and developing countries at once (Xu, Yun, 2018). Some works analyze the peculiarities of bilateral cooperation in science and technology of individual SCO countries (Varaprasad Sekhar, 2005). However, there are no studies devoted to the analysis of legal factors hampering the development of international scientific and technological cooperation between SCO countries. In this regard, this work summarizes the regulatory legal material, including national and international, on all SCO member-states: the Republic of India, the Republic of Kazakhstan, the People's Republic of China, the Kyrgyz Republic, the Islamic Republic of Pakistan, the Russian Federation, the Republic of Tajikistan, the Republic of Uzbekistan.

The objectives of this work necessitate the application of several research methods.

When considering legal factors of development of international scientific and technical cooperation, it is justified to apply a comparative legal method. The work contains a comparative analysis of both national legislation of the SCO countries on legal regulation of state scientific and technical policy and international agreements of the SCO member-states in the field of scientific and technical cooperation. The use of comparative legal method allowed determining the effectiveness of counteracting internal threats to international cooperation in the field of science and technology.

The use of formal legal method allowed to understand the content of legal rules enshrined in the national legislation of the ScO countries, to assess the quality of regulatory and legal regulation of relations arising in connection with scientific and technical activities. At the same time, more than ten normative acts of the SCO member-states regulating the basis of national state scientific and technical policy, including the issues of international cooperation, were studied. In addition, as part of this work bilateral and multilateral agreements between SCO countries in the field of scientific and technical cooperation were studied, and data on the existence of bilateral agreements in the field of science and technology between the individual states under study were summarized.

\section{Results}

Domestic legal factors affecting the development of scientific and technical cooperation. In the Russian Federation the basis for legal regulation of the state scientific and technical policy is contained in the Federal Law of 23.08.1996 № 127-FZ "On Science and State Scientific and Technical Policy" (On Science, 2019). This normative act regulates in detail such issues as legal status of subjects of scientific and scientific-technical activity, order of organization and principles of regulation of scientific and scientifictechnical activity, order of formation and implementation of state scientific-technical policy, state support of innovations. It also pays some attention to international scientific and technological cooperation, but most of these provisions are of a blanket nature and are specified in other sources. For example, involvement of foreign citizens in implementation of innovative scientific and technological projects is regulated by Article 20 of the Federal Law of 29.07.2017 № 216-FZ "On innovative scientific and technological centers and on amendments to certain legislative acts of the Russian Federation" (On Innovative, 2019).

Recently, more and more attention has been paid to the development of international scientific and technical cooperation in the Russian Federation. Thus, the Concept of International Scientific and Technical Cooperation of the Russian Federation was approved by Resolution of the Government of the Russian Federation No. TG-P8-952 dated February 8, 2019. In this Concept, state policy in this area is considered through the prism of scientific diplomacy - "a system of interaction between scientists, research teams, and organizations engaged in research and development, and the activities of government agencies related to it, aimed at developing international relations, taking into account the interests of the Russian Federation, the development of dialogue between the scientific and technological community and improving mutual understanding between peoples" (The concept, 2019).

However, the legal regulation of science and technology in the Russian Federation is not stable. The high dynamics of lawmaking in Russia often lead to the fact that subjects of scientific and innovation activity often face new unforeseen conditions of interaction between themselves and the state. A significant role is played by by-laws that periodically create unreasonable obstacles and complicate communication between scientific communities from foreign countries.

In the Russian Federation, organizations that are responsible for the development of science are represented primarily by state academies of science. A special role is played by the Russian Academy of Sciences, which provides scientific management of scientific research in the Russian Federation and conducts scientific research. Despite the fact that it is possible to create public academies of sciences in Russia, the state academies of sciences, as well as state scientific and educational institutions, demonstrate a greater contribution to science and efficiency (On Modern Problems, 2019).

The dependence of scientific institutions on the government significantly reduces their independence, makes them dependent on the political situation and to some extent limits the freedom of scientific creativity.

In the Republic of India, the main policy document in the field of science and technology is the Science, Technology and Innovation Policy 2013 (Science, 2013). It sets out the main elements of India's science, technology and innovation policy, national development goals and objectives for science and innovation and directions for attracting private funding for research and development. International cooperation is also an important focus of this document. It proposes to develop strategic bilateral and multilateral partnerships with other nations based on the principles of science diplomacy, technological synergy and technology acquisition. It is noteworthy that India's legal system has been significantly influenced by common law. It is reflected not only in the legal terms and designs used, but also in legal technology in general. This distinction complicates the interaction on legal aspects of scientific and technical cooperation between India and most of the SCO countries, which gravitate towards the Romano-Germanic legal system.

The People's Republic of China is one of the world leaders in the development of science and technology. This is due both to the implementation of successful foreign experience in science and technology management and to the well-thought-out state science and technology policy. Its basis is regulated by such documents as the Planning Program for the Improvement of the Quality of Science in the country in 2006-2010-2020; the State Long-term and Medium-term Planning Program for the Development of Talents for 2010-2020; the Law of the People's Republic of China on Science and Technology Progress of 1993. (as amended in 2007); the Law of PRC on the dissemination of scientific and technological knowledge, 2002; and the Law of PRC on Innovation Policy, 2002 (Anichkin et al., 2019). The goals of public policy in the field of science and technology, sources of funding for scientific research, and cooperation between scientific institutions and production enterprises are set out in the Law of PRC on Science and Technology Progress of 1993 (as amended in 2007, Law, 1993). At first glance, the functioning of the Chinese Academy of Sciences brings the Chinese system of organizations involved in science management closer to the Russian approach. However, since the early 2000s, there has been a steady downward trend in the centralization of science and innovation management in China (Ivanov, 2018). Nevertheless, the impact of state institutions on the scientific community in China remains significant. In addition, it should be noted that despite the liberalization of investment laws (in March 2019, China adopted a new law "On Foreign Investment", which significantly expanded the opportunities for foreign investment in the national economy) and the reduction of the "negative list" of areas for foreign investors, a number of areas of scientific research and technology remain closed to international cooperation. 
The Ministry of Foreign Trade of China has included in this list investments in human stem cell development, genetic diagnosis and the development and application of therapeutic technologies; investments in humanities and social sciences institutions; investments in geodesy, marine cartography, geodesy and aerial photography, ground surveys, boundary mapping of administrative areas, topographic maps, political zones of the world, maps of political areas of the country, provincial and lower political areas.

The basics of the public science and technology policy of the Islamic Republic of Pakistan are formulated in the National Science, Technology and Innovation Policy 2012. It is noted in this document that Pakistan has not yet become part of the global knowledge society, but the state is willing to make every effort to put the country on the path to excellence in all areas of modern science and technology (National, 2012). In terms of international science and technology cooperation, Pakistan's National Science, Technology and Innovation Policy places the cooperation with industrialized nations first, but also recognizes the importance of cooperation with developing countries, particularly with a view to adopting best practices and experiences.

The status of scientific organizations in the Islamic Republic of Pakistan is diverse. For example, the Pakistan Academy of Sciences is a non-governmental institution, the highest scientific organization in the country that brings together outstanding scientists (Pakistan, 2019). The Pakistan Council for Science and Technology, a number of other scientific, and research organizations are under the Ministry of Science and Technology (The review, 2020). In general, the legal regulation of scientific and technological activities in Pakistan is at an early stage of development, so that most of the relevant issues, including those related to international cooperation, remain without adequate legal regulation. In the Republic of Kazakhstan, the foundations of the state science and technology policy are set out in Law No. 407-IV of the Republic of Kazakhstan "On Science" dated 18 February 2011. Establishing the competence of state bodies in the field of science and technology, the legal status of subjects of science and technology, the procedure for management and financing of science and technology, this law in its most general form also affects international cooperation in the field of science (Article 29).

The National Academy of Sciences of the Republic of Kazakhstan is a republican public association, i.e. non-governmental organization. However, its role in the state scientific and technical policy is high because it takes part in the formation and implementation of scientific, scientific and technical and innovation policy, in the development of priority directions of science development, as well as draft regulatory legal acts in the scientific and technical sphere. In general, the Republic of Kazakhstan is characterized by a significant influence of the state in the scientific sphere. However, the lack of a comprehensive strategy for international cooperation in the field of scientific research, scientific and technological developments and innovation activity at the legislative level is a significant drawback (Matrasulov, 2017).

In the Republic of Tajikistan, the legal basis for the state science and technology policy is set out in the Law of the Republic of Tajikistan "On Science Activities and State Science and Technology Policy" of 2015. It defines the purpose and main directions of implementation of the state scientific and technical policy, main principles of the state regulation of scientific and technical activity and others. At the same time, this document does not pay significant attention to the sphere of international scientific and technical cooperation.

The Academy of Sciences of the Republic of Tajikistan, which ensures implementation and development of fundamental and applied research, coordinates academic, branch and university research activities, is a state scientific institution. However, some researchers question the effectiveness of the science management system. A. Kurbonov notes numerous problems with the state of science in the Republic of Tajikistan, including the poor quality of many studies, weak material and technical base and staff, and the inefficient use of funds allocated to finance science (Science and education, 2019). The main provisions of the state scientific and technical policy of the Republic of Uzbekistan are stipulated in the law "On science and scientific activity" of 2019. It not only defines the main principles and directions of the sphere of science and scientific activity, but also establishes the legal status and powers of the subjects of the sphere of science and scientific activity, contains norms on organization and financing of science and scientific activity. The Law also contains a number of general provisions on international cooperation in the sphere of science and scientific activity (Article 41). The public sector prevails in the field of scientific research. The leading scientific institution is the Academy of Sciences of the Republic of Uzbekistan (state institution). The main drawback is the declarative nature of the above norms enshrined in the national legislation of the Republic of Uzbekistan and the lack of a consistent policy to improve the legal regulation of scientific and technical activities. The main regulatory document defining the state scientific and technical policy of the Kyrgyz Republic is the Law "On science and on the basis of the state scientific and technical policy" dated 16 June 2017. It should be noted that among the principles of the science and technology policy it defines the principle of maximum use of the possibilities of the world science and international science and technology cooperation to ensure scientific and technical progress. In addition, the law contains a separate chapter on international scientific and technical cooperation, which defines the areas of cooperation (joint research, scientific conferences, mobility of scientists, etc.) (Anichkin et al., 2019).

The National Academy of Sciences of the Kyrgyz Republic is a state scientific institution. Most scientific institutions have state origin and propriety. Despite the significant updating of the legislative base on issues of legal regulation of scientific and scientific and technical activities, the practical implementation of the norms contained therein remains extremely weak. This fact demonstrates the actual absence of a science and innovation policy in the Kyrgyz Republic (Innovations, 2020). External legal factors affecting the development of scientific and technical cooperation within the SCO.

Legal factors related to the existence of partnerships between SCO countries depend on the existence of both bilateral agreements between states on scientific and technical cooperation and multilateral agreements.

Table 1 shows data on the existence of bilateral agreements on R\&D cooperation between the SCO countries.

Table 1. Matrix of bilateral R\&D cooperation in the SCO countries

\begin{tabular}{|c|c|c|c|c|c|c|c|c|}
\hline Country & Russia & China & India & Kazakhstan & Pakistan & Tadzhikistan & Uzbekistan & Kyrgyzstan \\
\hline Russia & & + & + & + & + & + & + & + \\
\hline China & + & & & + & & & & \\
\hline India & + & & & + & & + & & + \\
\hline Kazakhstan & + & + & + & & & + & + & \\
\hline Pakistan & + & & & & & + & + & \\
\hline Tadzhikistan & + & & + & + & + & & & \\
\hline Uzbekistan & + & & & + & + & & & \\
\hline Kyrgyzstan & + & & + & & & & & \\
\hline
\end{tabular}


As follows from the presented data, only Russia has bilateral agreements on scientific and technical cooperation with other SCO countries. China and Kyrgyzstan have the least number of such agreements with SCO countries, but their absence does not exclude the possibility of bilateral cooperation in other forms of scientific and technical cooperation. Lack of bilateral agreements may be compensated by participation of the same states in international regional organizations. For example, Kazakhstan, Russia, Tajikistan, Uzbekistan and Kirghizia, being members of the CIS, are parties to the Agreement on Cooperation in the Interstate Exchange of Scientific and Technical Information 2014. Multilateral agreement that forms the basis for long-term partnership in the field of scientific and technical cooperation between the SCO countries is the Agreement between the governments of the Shanghai Cooperation Organization member-states on scientific and technical cooperation in 2013. However, such agreements, not excluding the above, are largely of a programmatic and declarative nature and do not establish specific legal mechanisms for implementing the provisions contained therein.

\section{Conclusions}

Despite the presence in all SCO countries of a certain regulatory framework that reflects the features of the state scientific and technical policy, it should be noted that the degree of its practical implementation is different. In such countries as Tajikistan, Uzbekistan, Kyrgyzstan, in general, the correct provisions of laws on development of science and technology remain largely declarative due to the lack of clear legal mechanisms for their implementation. Lack of internal success and undeveloped legal institutions reduces the attractiveness of these countries as international partners for cooperation in science and technology. In turn, the high dynamism and lack of predictability of normative activities, including those in science, technology and innovation, significantly reduces the reliability of cooperation with a state such as the Russian Federation. Finally, the membership of the SCO countries in various legal families can make the process of harmonizing the national legislation of the SCO countries on scientific and technical cooperation somewhat more difficult. In addition, a study of the national legislations of the SCO countries showed that there are no separate legal acts specifically regulating the sphere of international scientific and technical cooperation.

In most of the SCO member states, the scientific community, due to the legal status of scientific organizations, is significantly dependent on the state. This negatively affects the independence of scientific organizations and makes them vulnerable to changes in the state and political situation.

The study of quantitative and qualitative characteristics of international legal regulation has shown that there are no international agreements between the SCO countries that establish a detailed mechanism for scientific and technical cooperation. However, not all SCO member-states are bound by bilateral agreements in this area.

Thus, to date, neither national legislation of the SCO countries, nor interstate agreements between them (both bilateral and multilateral) are ready to fully ensure effective legal regulation of international scientific and technical cooperation within the SCO. It seems that a possible option to address these problems could be the development of a model law for all ScO countries "On International Scientific and Technical Cooperation", which should be based on the provisions of international agreements between SCO countries on interaction and cooperation in science and technology. The provisions of these documents can be used for effective harmonization of national legislation of SCO member-states on scientific and technical policy for sustainable development, overcoming global problems and "big challenges" of our time.

\section{Acknowledgements}

The work was supported by RFBR (project No. 18-29-15011 "Principles, Sources and Peculiarities of Legal Regulation of International Scientific and Technical Cooperation and International Integration in the Field of Research and Technological Development in Russia and Foreign Countries of Shanghai Cooperation Organization").

\section{References}

Kandakova, G.V., Chirkova, M.B., Malitskaya, V.B., Pluzhnikova, N.V. (2016). Development of international scientific and technical cooperation in agrarian sphere of Russia: problems and prospects. Vestnik of Voronezh State Agrarian University, 4(51), 187-196. Haegeman, K., Sokolov, A., Spiesberger, M., Boden, M. (2020). Facilitating EU-Russian Scientific and Societal Engagement: Joint Efforts to Tackle Grand Challenges. Available from: https://www.researchgate.net/publication/270587416 Facilitating EURussian Scientific and Societal Engagement Joint Efforts to Tackle Grand Challenges

Kwok, K.C., Lau, L.J., Summers, T. (2019). EU-China Innovation Relations: From Zero-sum to Global Networks. Available from: https://www.igef.cuhk.edu.hk/igef media/working-paper/IGEF/67.pdf

Xu, B., Yun, L. (2018). International Collaboration Patterns and Effecting Factors of Emerging Technologies. Available from: https://www.ncbi.nlm.nih.gov/pmc/articles/PMC5135128/

Varaprasad Sekhar, D. (2005). Science and Technology Cooperation between India and China. International Studies, 42(3-4), 307327. https://doi.org/10.1177\%2F002088170504200308

On Science and State Science and Technology Policy. (2019). Federal Law of 23.08.1996 No 127-FZ (ed. from 26.07.2019). Available from: http://www.pravo.gov.ru

On Innovative Scientific and Technological Centers and on Amendments to Certain Legislative Acts of the Russian Federation. (2019). Federal Law of 29.07.2017 No 216-FZ (ed. from 26.07.2019). Available from: http://www.pravo.gov.ru

The concept of international scientific and technical cooperation of the Russian Federation. (2019). Approved by the Government of the Russian Federation on February 8, 2019 No TG-P8-952). Available from: https://france.mid.ru/upload/iblock/7f8/7f8aadb5de45b3a58103046d70eabef2.pdf

On Modern Problems of Public Academies of Sciences in the Russian Federation. (2019). Available from: http://iam.duma.gov.ru/node/8/4585/15993

Science, technology and innovation policy. (2013). Government of India. New Delhi: DST Publ.

Anichkin, E.S., Vasilyev, A.A., Tlepina, S.V., Kulikov, E.A., Rezinkin, A.Yu., Serebryakov, A.A. (2019). National Legal Regulation of Science and Scientific and Technical Cooperation in the SCO Countries: Comparative Aspect. Ekoloji, 28(108), 2659-2679.

Law of the People's Republic of China "On scientific and technological progress" from 01.10.1993. Available from: http://en.most.gov.cn/eng/policies/regulations/200412/t20041228 18309.htm

Ivanov, S.A. (2018). Science and technology policy of China: catch-up priorities and results. Izvestia Eastern Institute, 2(38), 6-23.

China's 2019 Negative List. (2019). Available from: https://www.1421.consulting/2019/07/chinas-2019-negative-lists/ 
National Science, Technology and Innovation Policy. (2012). Available from:

https://most.comsatshosting.com/Policies/National\%20Science, \%20Technology\%20and\%20Innovation\%20Policy\%202012.pdf

Pakistan Academy of Sciences. (2019). Introduction. Available from: https://www.paspk.org/introduction-to-the-academy/

Ministry of Science and Technology. Available from: https://most.gov.pk/

The review of innovative development of Kazakhstan. (2019). Available from:

https://www.unece.org/fileadmin/DAM/ceci/publications/icp5 r.pdf

Matrasulov, D. (2017). Science and education need fundamental reforms. Available from: https://www.gazeta.uz/ru/2017/10/19/science-education/

Innovations for sustainable development, (2020). Review of the Kyrgyz Republic. Available from: https://www.unece.org/fileadmin/DAM/ceci/publications/I4SD Kyrgyzstan/ECI CECI 25 RUS.pdf

\section{Citation:}

Anichkin, E.S., Vasilyev, A.A., Kulikov, E.A., Rezinkin, A. Yu., Serebryakov, A.A. (2020). Legal and environmental factors hindering the development of scientific and technical cooperation in SCO countries. Ukrainian Journal of Ecology, 10(5), 122-126. 